\title{
Colostrum and milk protein rankings and ratios of importance to neonatal calf health using a proteomics approach
}

\author{
Asger Nissen, ${ }^{*} \dagger$ Pia Haubro Andersen, ${ }^{\star} \ddagger$ Emøke Bendixen, $§$ Klaus Lønne Ingvartsen, $\dagger$ \\ and Christine Maria Røntved†\# ${ }^{1}$ \\ *Department of Large Animal Sciences, Faculty of Life Sciences, University of Copenhagen, Højbakkegård Allé 5, DK-2630 Tåstrup, Denmark \\ †Department of Animal Science, Faculty of Science and Technology, Aarhus University, Blichers Allé 20, PO Box 50, DK-8830 Tjele, Denmark \\ $\ddagger$ Swedish University of Agricultural Science, Department of Clinical Science, 75007 Uppsala, Sweden \\ §Department of Molecular Biology and Genetics, Faculty of Science and Technology, Aarhus University, Gustav Wieds vej 10, \\ 8000 Aarhus C, Denmark \\ \#CMR On-Site RD, Skjernvej 4A, Department of Physics and Nanotechnology, Post Box 68, DK-9220 Aalborg Øst, Denmark
}

\begin{abstract}
Administration of colostrum to the newborn calf before gut closure is pivotal to its health, because of the transfer of passive immunity. Traditionally, passive immunity has been attributed to the transfer of immunoglobulins although it is increasingly clear that multiple other factors contribute, including innate immune proteins, developmental factors, immunomodulatory factors, and the presence of cellular immunity. The objective of this study was to produce a comprehensive comparison of the bovine colostrum proteome and the milk proteome by applying 2-dimensional liquid chromatography-tandem mass spectrometry. Further, the objectives were to rank proteins mutually and generate protein ratios from the spectral counts of the 2 proteomes and ELISA to gain insight into which proteins could be of most relevance to neonatal calf health. To obtain an in-depth picture of the bovine colostrum and milk proteome, we compared the contents of different fractions from bovine colostrum and milk from our 2 previous studies. A total of 140 colostrum fluid-phase proteins and 103 milk fluid-phase proteins were detected. In the cellular fraction, 324 and 310 proteins were detected in colostrum and milk, respectively. In total, 514 proteins were detected, of which 162 were in the fluid phase. Of these, 50 proteins were exclusively seen in colostrum, 13 were exclusively seen in milk, and 99 were common to colostrum and milk. Ranking of proteins mutually and calculating protein ratios based on spectral counts and ELISA resulted in new information on how proteins were associated with the fluid or cellular fraction of the samples. Interestingly, despite lower counts/concentrations than the classical
\end{abstract}

Received July 9, 2016.

Accepted December 18, 2016.

${ }^{1}$ Corresponding author: cmr@cmr-on-site.dk proteins such as immunoglobulins, $\beta$-lactoglobulin, and lactotransferrin, several proteins appeared in higher or similar colostrum:milk spectral count ratios as these. Using this approach indicated, for example, that osteopontin, haptoglobin, milk amyloid A, and gelsolin may be interesting molecules to study in detail in their relation to calf health. Although the sensitivity, identification, and ranking of proteins varied between the 2 methods, and proteome analysis clearly suffers from low sensitivity, we believe that this idea and approach of generating ratios and ranking proteins can contribute new information and perspectives on how to prioritize the importance of multiple proteins, beyond immunoglobulins, in relation to neonatal calf health.

Key words: Bos taurus, colostrum proteome, milk proteome, transfer of passive immunity

\section{INTRODUCTION}

The period just after birth is critical in neonatal life. The neonate calf has an immature immune system and is exposed to many environmental challenges. The gut epithelium loses the ability to take up massive loads of proteins from the colostrum approximately 24 $\mathrm{h}$ postpartum, in a process referred to as gut closure (Stott et al., 1979; Bush and Staley, 1980); thus, early administration of colostrum to the newborn calf, before gut closure, is pivotal to health and survival and has traditionally been attributed to the transfer of passive immunity (TPI) via immunoglobulins (Weaver et al., 2000). Proteins other than immunoglobulins that are involved in the humoral immune system could play a role in the neonate. This could include, for example, complement factors, antimicrobial peptides, and immunomodulatory factors. Further, developmental factors transferred from colostrum are believed to play important roles both locally in the calf's gastrointestinal (GI) tract and systemically in the calf (Stelwagen et 
al., 2009; Wheeler et al., 2012). The biological mechanism of TPI ensures that these components are transferred to the neonatal calf. At gut closure, the role of colostrum shifts from being immunological to primarily nutritional and growth, which prevents further absorption of intact immunoglobulins, proteins, and peptides from colostrum or milk.

Indeed, cow milk also contains immunologically important proteins, although these are in relatively low amounts and are thus believed to have little biological significance compared with that of colostrum (Stelwagen et al., 2009; Nissen et al., 2013). The proposed primary immunological function of these proteins is to protect the dam's udder from developing mastitis caused by infection with extra-mammary pathogenic bacteria (Rainard and Riollet, 2006). A second immunological function is to provide local immunity to the calf's GI tract, which readily may be infected with environmental pathogens.

The contribution of colostrum to the neonatal calf's health via cellular immunity has been the subject of research (Le, 1996). The cells present in colostrum consist mainly of leukocytes and mammary epithelial cells. Besides providing protection to the mammary gland itself, the leukocytes serve a dual role of contributing with proteins to the fluid phase (Stelwagen et al., 2009) and also directly contributing to the neonatal calf's health locally by translocating to the mucosa in the GI tract of the calf or systemically by translocating from the GI tract to the calf's blood circulation (Le, 1996).

Several researchers have investigated the changes in proteins during transition from colostrum to milk. Yamada et al. (2002) used 2-dimensional electrophoresis followed by microsequencing and MS and identified 29 proteins. Reinhardt and Lippolis (2008) explored the changes in the proteome of milk fat globule membranes by shotgun proteomics and isobaric tags for relative and absolute quantitation (iTRAQ; $>138$ proteins detected). Senda et al. (2011) used an approach similar to Yamada et al. (2002) and detected 25 proteins, and Le et al. (2011) applied ion-exchange separation combined with MS to provide semiquantitative spectral countingbased analysis of 293 proteins. More recently, Zhang et al. (2015) used shotgun proteomics and a dimethyl labeling approach to quantify the changes between colostrum and milk (212 proteins detected).

Previously, we published 2 comprehensive proteomebased studies of the of the proteins present in bovine colostrum sampled from the first milking after calving and in milk sampled on d 10 (Nissen et al., 2012, 2013). These results allow us to investigate whether biologically active proteins other than immunoglobulins were exclusive to colostrum or present in higher concentrations in colostrum than in milk. The aims of the present study were, first, to compare proteins in colostrum and milk from healthy animals, by mapping the unique complementary proteins as well as common proteins in colostrum and milk. Proteins were grouped according to their relative presence in either fluid phase or cellular fraction, or both. The second aim was to conduct a semiquantitative spectral count (SC) analysis to rank proteins and estimate protein abundance in the 2 samples. Finally, we calculated protein ratios between colostrum and milk from the SC as well as from preselected proteins analyzed by ELISA to investigate whether this novel approach could be used to generate new knowledge and perspectives on how to prioritize the importance of multiple proteins in relation to neonatal calf health beyond the immunoglobulins.

\section{MATERIALS AND METHODS}

This investigation was based on the results previously reported for proteins identified in colostrum (Nissen et al., 2012) and milk (Nissen et al., 2013). Both publications contain a thorough description of the procedures of fractionation and analysis; therefore, only a brief summary and an illustration of the fractionation and sample processing is presented here (Figure 1).

\section{Animal Health and Milk Sampling}

Composite colostrum and milk were collected on $\mathrm{d} 1$ and 10 postpartum, respectively, from 4 healthy Danish Holstein-Friesian cows in second lactation. The cows had been dried off 5 to 7 wk before calving. Each cow was milked twice a day at 0700 and $1600 \mathrm{~h}$. Udder health and body temperature were recorded in the period from parturition (d 1, colostrum sampling; cut-off value as healthy $<39.1^{\circ} \mathrm{C}$ ) to d 10 (milk sampling; cutoff value healthy $<37.9^{\circ} \mathrm{C}$ ). Udder inflammation based on foremilk strippings was scored using a semiquantitative cow-side test, California Mastitis Test (CMT; Kruuse, Marslev, Denmark; Pyörälä, 2003). The milk was collected immediately after calving and was accepted if CMT score was $<3$. On d 10 (milk sampling), milk was accepted if the CMT score was $<2$. Bacteriological analyses were done on foremilk samples according to National Mastitis Council guidelines on the first 6 milkings and on d 10 and were negative for major bacterial pathogens (National Mastitis Council, 1999). Further, milk samples were collected at the first 6 milkings postpartum and on d 10 and analyzed for SCC in a diagnostic dairy laboratory (Eurofins Steins Laboratory, Holstebro, Denmark). All collected milk samples for 2-dimensional liquid chromatography-tandem mass spectrometry (2D-LC-MS/MS) analysis had SCC $<2.9 \times 10^{6} / \mathrm{mL} \pm 8.0$ (colostrum, d 1) and SCC $<9.4$ 
$\times 10^{4} / \mathrm{mL} \pm 8.0$ (milk, d 10). Hence, all cows were considered to have healthy udders. Milk composite samples (representing the entire milk collected during milking) were collected from the 4 cows. The composite sample from each cow was pooled in the laboratory and used for the proteome analysis. The process of milk sampling and pooling is illustrated in Figure 1.

\section{Fractionation of Raw Colostrum and Milk}

In total, 6 colostrum and 6 milk samples were obtained. For each of the cow samples-whole nonfractionated colostrum or milk (NF), free of cells and fat (F1), and the cell pellet fraction (F2) - a pool was made from the 4 cows in replicates. An additional pool of milk from 4 cows was constructed, divided into 2 , and used for preparation of the 3 whey fractionations: acidification (F3), filtration (F4), and centrifugation (F5). The process resulted in 2 replicates of each fraction (NF, F1 to F5) and each fraction replicate was then analyzed once by 2D-LC-MS/MS. The 4 fractionation techniques thus resulted in 5 fractions (F1 to F5) in addition to the whole nonfractionated milk (NF). In total, this resulted in 24 samples to be analyzed. In this study, data from fractions NF, F1, F3, F4, and F5 were combined into one group termed the "fluid-phase fraction" and F2 was termed the "cellular fraction" (Figure 1). Only validated proteins; that is, proteins present in both replicates of each fractionation techniques from the previous 2 studies were included in this study. The processed results on colostrum and milk are reported in the Supplemental Material (File A; https://doi. org/10.3168/jds.2016-11722).

\section{Protein Detection and 2D-LC-MS/MS}

The protein concentration was determined before pooling the samples (on a volume or protein weight basis) and in NF and fractions F1 to F5 before proteome analysis (Nissen et al., 2012, 2013). Further, colostrum and milk samples were collected and analyzed in a diagnostic dairy laboratory (Eurofins Steins Laboratory) for total protein content.

A detailed description of the shotgun proteome (2D-LC-MS/MS) analysis performed on the NF and fractions $\mathrm{F} 1$ to F5, including protein precipitation, digestion, sterile filtration, and peptide elution is given in Nissen et al. (2012, 2013). A Q-Star Elite mass spectrometer (Applied Biosystems, Foster City, CA) was used for the final 2D-LC-MS/MS analysis.

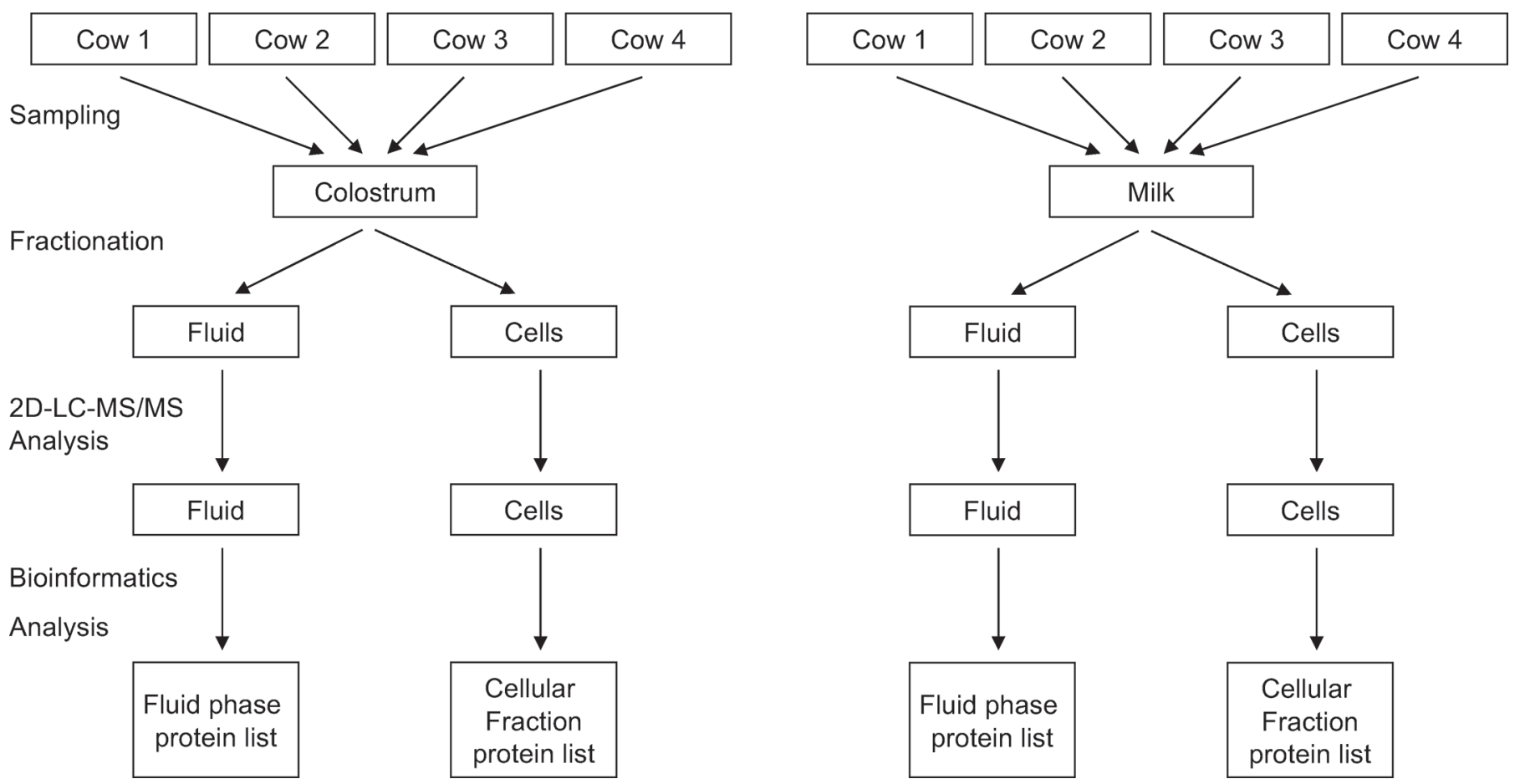

Figure 1. The experimental design: colostrum or milk from 4 cows was separated into several fluid fractions and a cellular fraction using multiple fractionation techniques. Two replicates were constructed of all fractions (fluid and cells). After 2-dimensional liquid chromatographytandem mass spectrometry (2D-LC-MS/MS) analysis, only proteins present in both replicates of each fractionation technique were considered valid. Detailed individual colostrum and milk diagrams and descriptions of the fractionation techniques can be found in Nissen et al. (2012, 2013) 


\section{Database Searching, Spectral Counts, and Gene Ontology Analysis}

The data files from the 2D-LC-MS/MS analysis were searched with the UniProt Bos taurus database as described by Nissen et al. (2012, 2013). Briefly, protein sequences for the target database were obtained from UniProtKB (Wu et al., 2006) database (Release 14.8/56.8; http://www.uniprot.org/help/uniprotkb) with only Bos taurus selected for matching. To evaluate and increase the confidence of the protein identification, a target-decoy database search was applied (Elias and Gygi, 2007, 2010). The construction of the decoy part of the database, the search of the raw data files with the ProteinPilot 1.0 software (Applied Biosystems), and data modification are described in Nissen et al. (2012). Proteins were accepted according to a protein score of 1.3, equivalent to $95 \%$ confidence. Protein matches were considered valid if the protein was detected in both replicates of each fractionation technique. For protein names reported as a short abbreviation, a BLAST search was performed (http:// www.uniprot.org/blast/). The resulting alternative name was determined based on strong homology to a better-characterized protein, having a highly similar AA sequence. The alternative name was added to the result file (Tables 1 to 4 and Supplementary File A; https://doi.org/10.3168/jds.2016-11722) in parentheses along with the degree of similarity (Supplementary File A). Repeatability and false discovery rate (FDR) analysis was performed as presented in Nissen et al. (2012, 2013).

A semiquantitative analysis was performed for fluid phase proteins and the simultaneously detected cellular fraction proteins by counting the ProteinPilots peptide spectra. The total number of $\geq 95 \%$ confidence spectra for proteins detected in both replicates was reported by adding the 2 replicates' numbers, and a ranking of the protein abundance was based on this. To improve the accuracy of the ranking analysis, the SC values were normalized with molecular weight values obtained from UniProt (www.uniprot.org). The result is presented in the ranking of the protein abundance. For the proteins common to both colostrum and milk, a ratio was reported by dividing the SC of the two, resulting in an analysis weight:weight ratio. A more biologically correct ratio was calculated by taking the difference in protein concentration of $\mathrm{F} 5$ in colostrum and milk into account (calculation further presented in Results).

Finally, a Gene Ontology (GO) analysis of the proteins was performed. To avoid exaggerated detailed annotation, a slimmed set of the GO annotation terms was conducted using the AmiGO web service from Gene Ontology (version 1.8; Ashburner et al., 2000).

\section{Supportive Protein Analysis}

Eight commercial ELISA kits were used to verify and quantify the protein concentration in whole nonfractionated colostrum and milk (NF) including total Ig, lactotransferrin (LF), apolipoprotein-C-I (APO-C-I), lipopolysaccharide binding protein (LBP), milk amyloid protein A (MAA), haptoglobin (HP), transforming growth factor $\beta-2$ (TGF-b2) and transforming growth factor $\beta-1$ (TGF-b1). Before analysis, all NF samples were kept at $-20^{\circ} \mathrm{C}$ until preparation for the different ELISA. All analyses were performed as presented in Nissen et al. (2012, 2013), except that APOC-I (1:12,000, USCN Life Science Inc., Wuhan, China) was included. The ratio between the different milkings and milking \#1 was calculated by a simple division: ratio $=\mathrm{SC}$ milking $\# 1 / \mathrm{SC}$ milking $\# 2,3,4,5$, and 6 . All numerical results and coefficients of variation for the samples are presented in Supplemental Materials (File D; https://doi.org/10.3168/jds.2016-11722).

\section{RESULTS}

The presented results are based on proteins detected in both replicates of each applied fractionation technique (NF, F1 to F5) from clinically and para-clinically verified healthy cows. The average protein concentration was $135.0 \pm 8.0$ and $34.0 \pm 3.0 \mathrm{mg} / \mathrm{mL}$ in colostrum and milk, respectively, giving a ratio of 4.0 between the 2 samples. In the final protein result files, the dominant caseins $\left(\alpha_{\mathrm{S} 1}, \alpha_{\mathrm{S} 2}, \beta\right.$, and $\left.\kappa\right)$ and immunoglobulins $\left(\operatorname{IgG}_{1}\right.$, $\mathrm{Ig}_{2}$, IgA, and $\left.\operatorname{IgM}\right)$ and the common contaminant proteins keratin and trypsin were removed. In total, 140 colostrum proteins and 103 milk proteins were detected in the fluid phase, and 324 colostrum proteins and 310 milk proteins were detected in the cellular fraction. The FDR was low (colostrum: $1.0 \% \pm 1.0$; milk: $1.0 \% \pm$ 1.0). The total list of proteins detected in colostrum and milk is presented in Supplemental Material (File A, https://doi.org/10.3168/jds.2016-11722). Further, the full complement (fluid phase and cellular fractions) of colostrum to milk and the complement of milk to colostrum is presented in Supplemental Material (Files B and C, respectively; https://doi.org/10.3168/jds.201611722). In total (colostrum and milk), 162 proteins were detected in the fluid phase, and the results presented in Tables 1, 2, 3, and 4 were based only on these proteins. Proteins from the cellular fractions are presented in Supplemental Material (Files A, B, and C).

\section{Overview of Colostrum and Milk Proteome}

Figure 2 presents, in a Venn diagram, the difference in numbers of proteins detected in the fluid and cellular 
Table 1. Proteins $(n=50)$ found in the fluid phase of colostrum exclusively $(n=41)$ and those also found in the cellular fraction $(n=9)$ of colostrum (but not in milk)

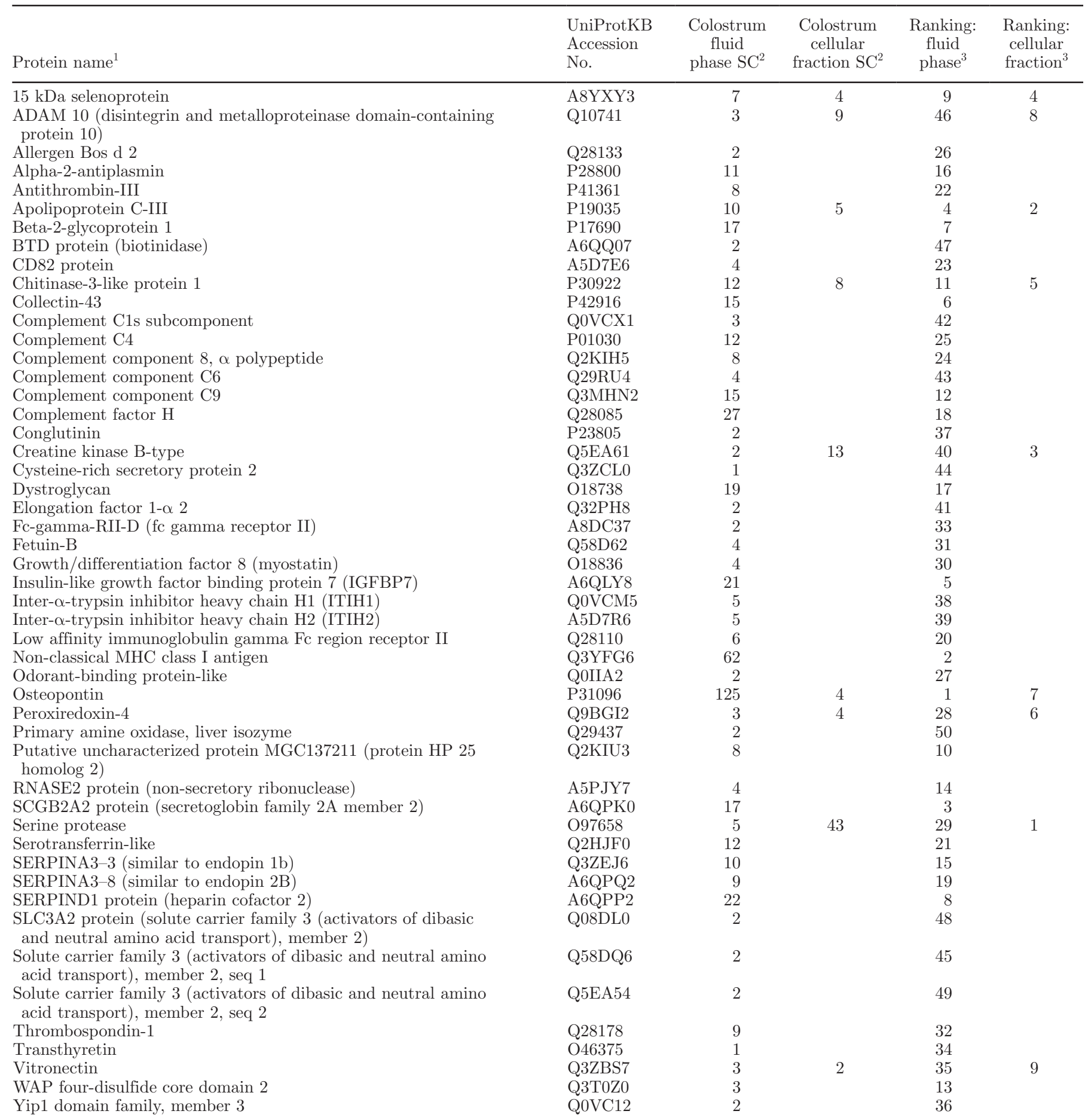

${ }^{1}$ Proteins whose names are reported as a short abbreviation also include an alternative name in parentheses, obtained by the BLAST search (www.uniprot.org/blast/).

${ }^{2}$ Result of the spectral count (SC) analysis.

${ }^{3}$ Ranking of the proteins based on molecular weight-normalized SC values. 
Table 2. Proteins $(\mathrm{n}=13)$ found in the fluid phase of milk exclusively $(\mathrm{n}=12)$ and those also found in the cellular fraction $(\mathrm{n}=1)$ of milk (but not in colostrum)

\begin{tabular}{|c|c|c|c|c|c|}
\hline Protein name ${ }^{1}$ & $\begin{array}{l}\text { UniProtKB } \\
\text { Accession } \\
\text { No. }\end{array}$ & $\begin{array}{c}\text { Milk } \\
\text { fluid } \\
\text { phase SC }\end{array}$ & $\begin{array}{c}\text { Milk } \\
\text { cellular } \\
\text { fraction SC }\end{array}$ & $\begin{array}{l}\text { Ranking: } \\
\text { fluid } \\
\text { phase }^{3}\end{array}$ & $\begin{array}{l}\text { Ranking: } \\
\text { cellular } \\
\text { fraction }^{3}\end{array}$ \\
\hline ADP-ribosylation factor $1,2,3$ & P84080 & 2 & & 9 & \\
\hline Carboxypeptidase B2 & Q2KIG3 & 2 & & 4 & \\
\hline Cellular repressor of E1A-stimulated genes 1 & Q148D9 & 30 & & 6 & \\
\hline Fatty acid-binding protein, heart & P10790 & 44 & & 12 & \\
\hline Peptidyl-prolyl cis-trans isomerase FKBP1A & P18203 & 7 & & 13 & \\
\hline Ras-related protein Rab-18 & Q0IIG8 & 2 & & 7 & \\
\hline Sodium-dependent phosphate transport protein $2 \mathrm{~B}$ & Q27960 & 5 & & 2 & \\
\hline Superoxide dismutase $[\mathrm{Cu}-\mathrm{Zn}]$ & $\mathrm{P} 00442$ & 2 & & 10 & \\
\hline Syndecan-2 & Q58DD4 & 3 & & 8 & \\
\hline TOMM22 protein (mitochondrial import receptor subunit homolog) & A6QPI6 & 4 & & 11 & \\
\hline
\end{tabular}

${ }^{1}$ Proteins whose names are reported as a short abbreviation also include an alternative name in parentheses, obtained by the BLAST search (www.uniprot.org/blast/).

${ }^{2}$ Result of the spectral count (SC) analysis.

${ }^{3}$ Ranking of the proteins based on molecular weight-normalized SC values.

fractions of colostrum and milk. As expected, the number of proteins detected in the colostrum fluid phase (n $=140$ ) was greater than that in the milk fluid phase (n $=103$ ). Colostrum contained 50 proteins that were not detected in milk, and milk contained 13 proteins not detected in colostrum. In the cellular fraction, the milk cellular complement to colostrum cells contained 99 proteins that accounted for $32 \%$ of the identified milk proteins. In this respect, and throughout the study, complement means the mathematical complement, not to be confused with complement factors from the immune system. Colostrum's cellular complement to milk cells consisted of 97 proteins being exclusively detected in colostrum, which accounted for approximately 30\% of its proteins. However, the difference is not large and can probably be attributed to the different cell types present in colostrum and milk (data not presented).

In the following $\mathrm{SC}$ for all proteins is presented as numbers in the columns (Tables 1, 2, 3, and 4). This number gives a measure of the relative concentration of the protein. The proteins were ranked based on SC by numbering them for both the fluid phase and the cellular fraction.

\section{Proteins Present Only in Colostrum}

The protein table presented in the Supplementary Material (File A, https://doi.org/10.3168/jds.201611722) was analyzed to determine the fluid-phase complement of colostrum to milk. Table 1 presents the 50 proteins found exclusively in bovine colostrum fluid phase compared with milk. In the table, 41 proteins were only detected in the fluid phase, whereas 9 were detected in both the fluid phase and the cellular fraction. The presence of cytokines was exemplified by osteopontin $(\mathrm{SC}=125)$, a common milk protein, being the highest ranking and most abundant of the proteins exclusively detected in colostrum. The lowest SC was for transthyretin and cysteine-rich secretory protein 2 , both of which had an SC of 1.

A large number of complement factors proteins was found, including the components $\mathrm{C} 1 \mathrm{~s}, \mathrm{C} 4,8 \alpha$ polypeptide, C6, C9, and factor $\mathrm{H}$. Antimicrobial proteins (e.g., collectin-43 and conglutinin) were exclusively detected in the colostrum fluid phase. Besides these very important immune system proteins, proteins important in growth and development were present. These included growth/differentiation factor 8 (also known as myostatin), insulin-like growth factor binding protein 7 (IGFBP7), and vitronectin. Proteins exhibiting an inhibitory effect on proteolytic activity were also present, including $\alpha$-2-antiplasmin, inter- $\alpha$-trypsin inhibitor heavy chain (ITIH1), inter- $\alpha$-trypsin inhibitor heavy chain H2 (ITIH2), SERPINA3-3, SERPINA3-8, and SERPIND1 protein.

\section{Proteins Present Only in Milk}

Table 2 presents the 13 proteins found in the bovine milk fluid phase, 1 of which was also detected in the cellular fraction (lactoperoxidase). The highest-ranking protein was ALB $(\mathrm{SC}=384)$. A BLAST research of ALB identified it as serum albumin, which was also found in colostrum; however, because the grouping mechanism in ProteinPilot separated the 2 entities, ALB protein was left in the results table as being a milk protein only 
(Table 2). Four proteins shared the lowest SC score: ADP-ribosylation factor 1, 2, 3; carboxypeptidase B2; Ras-related protein Rab-18; and superoxide dismutase $[\mathrm{Cu}-\mathrm{Zn}]$. No complement factors or protease inhibitors were detected exclusively in the bovine milk fluid phase. One antimicrobial protein found was the previously mentioned highly abundant and first-ranking protein lactoperoxidase, which was detected in both the fluid and cellular fraction. Another possible antimicrobial protein was mucin 15. The presence of developmental factors was possibly exemplified by cellular repressor of E1A-stimulated genes 1 (CREG1).

\section{Proteins Present in Both Colostrum and Milk}

Table 3 presents the 81 proteins common to the fluid phase of both colostrum and milk. The protein group was composed of 32, 19, 6, and 24 proteins in Figure 2. For clarity, ranking based on SC of the proteins in the cellular fraction was left out. A tentative qualitative measure of the relative change in concentration between the 2 sampling points (i.e., colostrum and milk) is also presented.

As expected, the major whey fraction proteins were present in both samples, being $\beta-\mathrm{LG}$ (top ranking) and $\alpha$-LA. Among the common proteins, $\alpha$-LA was ranked second after $\beta$-LG in the milk sample, but was ranked third in the colostrum sample, where serum albumin was ranked second. Complement factors were present in both samples, including complement factors $\mathrm{C} 3, \mathrm{~B}$, and I.

Acute phase proteins, including milk amyloid A protein, ceruloplasmin, hemopexin, lactotransferrin (lactoferrin, LF), LPS-binding protein (LBP), and LPS binding receptor monocyte differentiation antigen CD14 were detected. Several protease inhibitors were present: $\alpha$-1-antiproteinase, endopin $2 \mathrm{~B}$, endopin $2 \mathrm{C}$, inter- $\alpha$-trypsin inhibitor heavy chain H4 (ITIH4), serpin A3-1, SERPINA3-5, and SERPINA3-6.

Table 4 presents the 18 additional proteins common to both colostrum and milk, either being detected in the colostrum cellular fraction and in the milk fluid phase fraction or vice versa. The protein group was composed of 3,6 , and 9 proteins from Figure 2. The highest-ranking proteins were cathelicidin-1 in colostrum and fibroblast growth factor-binding protein 1 in milk. Always included were the acute phase protein haptoglobin and several immune proteins - cathelicidin-1, cathelicidin-2, and peptidoglycan recognition protein.

\section{Proteins Related to the Cellular Fraction}

The cytoskeleton protein actin is a housekeeping protein and serves no purpose in the extra-cellular space under nonpathological conditions. The concentration of actin can therefore serve as a measure of how much protein the cells contributed to colostrum and milk simply due to unspecific cell lysis. Our unadjusted results showed that the presence of cellular proteins due to cell lysis was largely constant across the 2 sample types, colostrum and milk. In the fluid phase of colostrum, actin scored 20 in the SC analysis and 400 in the SC analysis of the cell pellet. In the fluid phase of milk, actin scored 28 in the $\mathrm{SC}$ analysis and 410 in the SC analysis of the cell pellet. Consequently, around 5.0 to $6.8 \%$ of the proteins present in the cellular fraction and in the fluid phase can be attributed to leaking following cell lysis.

\section{Time-Elapsed Quantification by ELISA}

Eight selected proteins were quantified by ELISA and the results are presented in Figure 3. The protein MAA was only quantified until milking 6 ; the protein concentration of sample collected at milking 7 was below the ELISA detection limit. Hence, calculation of the ratio in milk (milking 20 on d 10) was not possible $(0.0 \mathrm{ng} / \mathrm{mL})$ and therefore left blank. File D in the Supplemental Material (https://doi.org/10.3168/ jds.2016-11722) presents the numerical values of the ELISA measurements. It can be seen in Figure 3 and the Supplemental Material (https://doi.org/10.3168/ jds.2016-11722) that most of the proteins were at their highest concentrations in early colostrum samples. However, 3 proteins had slightly higher concentrations at the second milking. In contrast, all proteins reached their lowest concentrations in the milk samples. Hence, the 2 sampling points ( 1 colostrum and $\mathrm{d} 10$ milk) were validated for comparison to identify proteins unique to colostrum and milk. When considering the concentration range for colostrum, the order of proteins was Ig $>\mathrm{LF}>$ APO-C-I $>$ LBP $>$ MAA $>$ HP $>$ TGF-b2 > TGF-b1. For milk, the order was similar except that for MAA: $\mathrm{Ig}>$ LF $>$ APO-C-I $>$ LBP $>$ HP $>$ TGF-b2 $>$ TGF-b1 > MAA. Interestingly, this order changed markedly when protein ratios were calculated: MAA $>\mathrm{Ig}>\mathrm{HP}>\mathrm{LF}>$ APO-C-I $>$ LBP $>$ TGF-b2 > TGF-b1. Moreover, when comparing the kinetics of the ratios, 3 different patterns were observed: (1) a pattern that followed the characteristic of Ig with an almost linear increase from sample points 1 to 7 that included Ig, LF, APO-C-1 and MAA; (2) a pattern with a curve starting near zero at sample point 1 , followed by a flat low increase until sample point $6(\mathrm{~d} 0-3)$, where the largest increase occurred that included LBP, HP, and TGF-b2; and (3) a pattern with similar ratios at the first 3 sample points (d $0-1.5$ ) followed by a steady increase to sample point 6 for TGF-b1. 


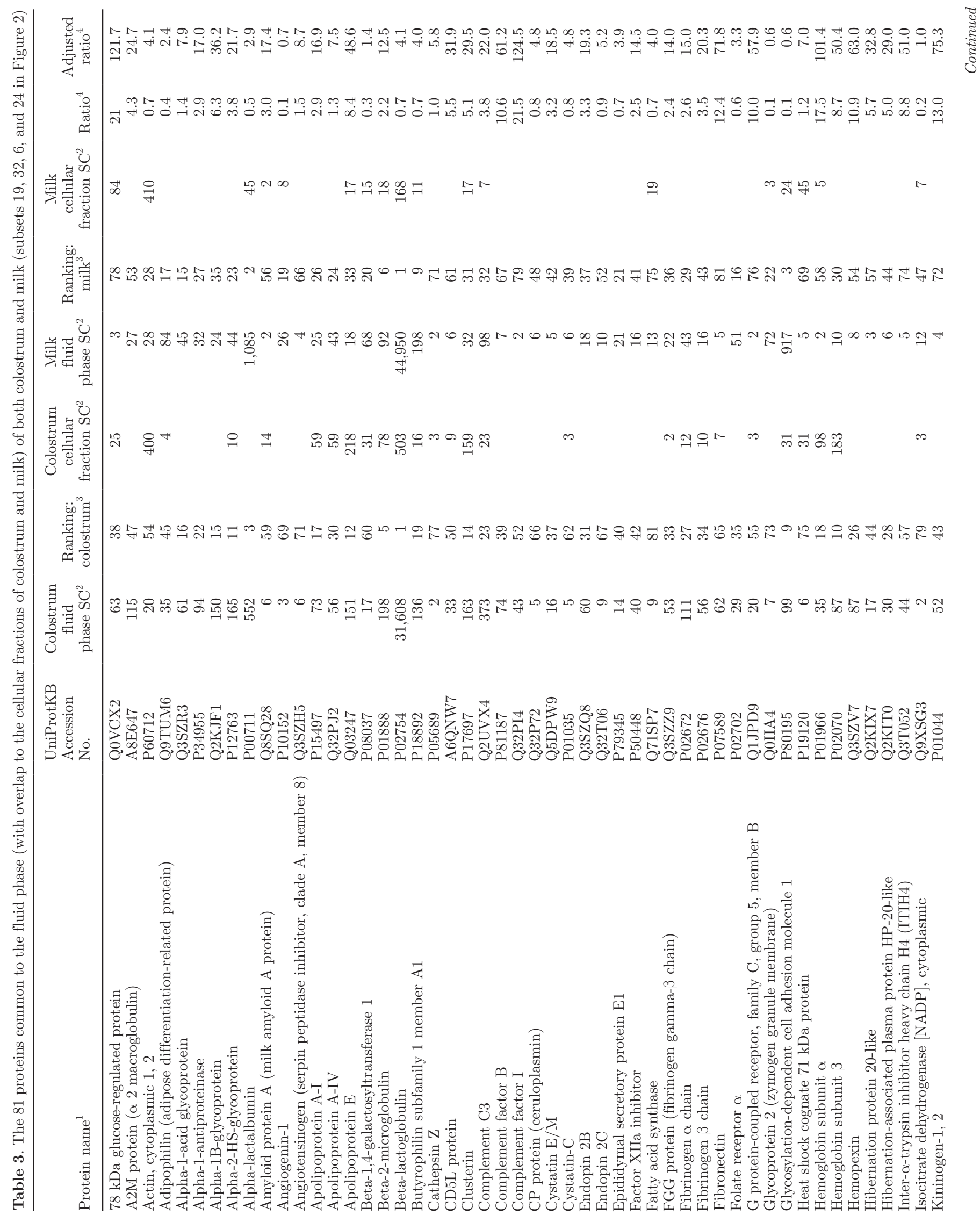




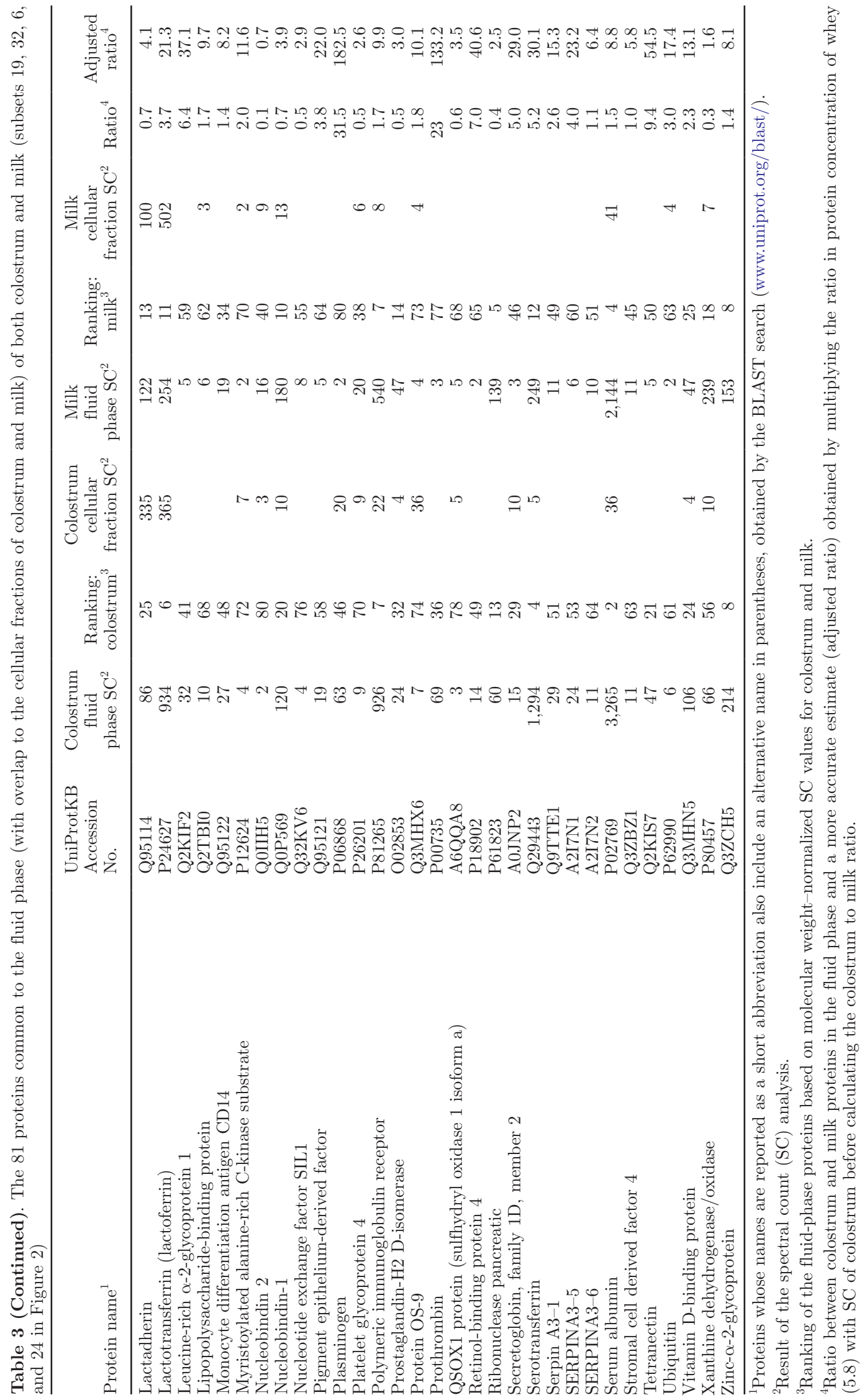


Table 4. The additional 18 proteins common to both colostrum and milk and detected in the cellular fractions (with overlap to fluid phases) (subsets 3, 6, 9, and 0 in Figure 2)

\begin{tabular}{|c|c|c|c|c|c|c|c|}
\hline Protein name ${ }^{1}$ & $\begin{array}{l}\text { UniProtKB } \\
\text { Accession } \\
\text { No. }\end{array}$ & $\begin{array}{l}\text { Colostrum } \\
\text { fluid } \\
\text { phase } \mathrm{SC}^{2}\end{array}$ & $\begin{array}{l}\text { Ranking: } \\
\text { colostrum }^{3}\end{array}$ & $\begin{array}{l}\text { Colostrum } \\
\text { cellular } \\
\text { fraction } \mathrm{SC}^{2}\end{array}$ & $\begin{array}{c}\text { Milk } \\
\text { fluid } \\
\text { phase SC }\end{array}$ & $\begin{array}{l}\text { Ranking: } \\
\text { milk }^{3}\end{array}$ & $\begin{array}{c}\text { Milk } \\
\text { cellular } \\
\text { fraction } \mathrm{SC}^{2}\end{array}$ \\
\hline Annexin A5 & P81287 & & & 25 & 3 & 9 & 38 \\
\hline Cathelicidin-2 & P19660 & 6 & 4 & 26 & & & 55 \\
\hline Fibroblast growth factor-binding protein 1 & Q9MZ06 & & & 11 & 28 & 1 & 7 \\
\hline GANAB protein (neutral $\alpha$-glucosidase) & A6QNJ8 & 2 & 9 & 12 & & & 3 \\
\hline Histone H4 (DCK protein) & P62803 & 2 & 5 & 41 & & & 51 \\
\hline Lipoprotein lipase & $\mathrm{P} 11151$ & & & 2 & 37 & 2 & 31 \\
\hline Lithostathine & P23132 & & & 5 & 6 & 3 & 6 \\
\hline Peptidoglycan recognition protein & Q8SPP7 & 30 & 2 & 109 & & & 258 \\
\hline Peptidyl-prolyl cis-trans isomerase B & P80311 & & & 4 & 2 & 8 & 12 \\
\hline Proactivator polypeptide & P26779 & & & 3 & 5 & 7 & \\
\hline Protein disulfide-isomerase & P05307 & 2 & 8 & 18 & & & 7 \\
\hline
\end{tabular}

${ }^{1}$ Proteins whose names are reported as a short abbreviation also include an alternative name in parentheses, obtained by BLAST search (www. uniprot.org/blast/).

${ }^{2}$ Result of the spectral count (SC) analysis.

${ }^{3}$ Ranking based on molecular weight-normalized SC values for colostrum and milk.

\section{Ranking and Ratios of Protein by Proteome and ELISA}

When comparing the method sensitivity for proteome analysis and ELISA, the ELISA was able to detect and quantify all 8 proteins in colostrum, and 7 out of 8 proteins in milk. In comparison, proteome analysis was able to quantify 4 of 8 proteins twice (in replicates) in both colostrum and milk fluid phase, including Ig, LF, LBP, and MAA. Indeed, TGF-b2 was also found among the listed proteins in colostrum but only in 1 of 2 replicates in the fraction free of cells and fat (Nissen et al., 2012), and did therefore not pass the analysis criteria. Transforming growth factor-b1 was not detected either in colostrum or milk. Although APO-C-I was quantified by ELISA in concentrations equal to that of LBP in both colostrum and milk, it was not identified by proteome analysis, which detected only APO-C-III as a unique protein in colostrum. In colostrum, the 6 proteins including APO-C-III were ranked as follows: Ig (not shown) $>$ LF $>$ HP $>$ MAA $>$ APO-C-III $>$ LBP based on their number of SC; in milk, the same proteins were ranked as Ig (not shown) $>\mathrm{LF}>\mathrm{HP}>\mathrm{LBP}>$ MAA > APO-C-III.

The SC analysis ratios for the 3 common fluid proteins LF, MAA, and LBP were 3.7, 3.0, and 1.7, respectively. The protein concentration of the whey obtained in F5 was $117.8 \pm 7.0 \mathrm{mg} / \mathrm{mL}$ in colostrum and $9.1 \pm$ $1.1 \mathrm{mg} / \mathrm{mL}$ in milk (data not presented). Subtracting the immunoglobulin content (Supplementary Materials; File D, https://doi.org/10.3168/jds.2016-11722) gave 47.8 and $8.6 \mathrm{mg} / \mathrm{mL}$, respectively, resulting in a ratio of 5.8. This ratio was multiplied by $\mathrm{SC}$ of colostrum before calculating the adjusted ratio for colostrum to milk, as presented in Table 3 . The adjusted ratios were $21.3,17.4$, and 9.7 for LF, MAA, and LBP, respectively, ranking these mutually as LF $>$ MAA $>$ LBP by ratio. Hence, the proteome differed in ranking of both SC and ratios compared with the ELISA protein concentration and ratios.

\section{Gene Ontology Complement of Colostrum and Milk}

We performed a GO analysis to clarify whether any changes occurred in the functional potential of proteins in colostrum and milk. The results according to the "biological process" GO term are presented in Figure 4. Both colostrum and milk had proteins annotated in all terms of the top-level biological process category. The proteins in colostrum $(\mathrm{n}=140)$ resulted in more annotations (549 annotations) than the milk proteins ( $\mathrm{n}=103 ; 475$ annotations). The proteins in colostrum showed increased activity in many groups; for example, biological regulation, metabolic process, regulation of biological process, positive regulation of biological process, and immune system process. In contrast, the milk proteins showed increased activity in localization, establishment of localization, signaling, reproduction, 
Colostrum Fluid Phase 140 proteins
Milk Fluid Phase

103 proteins

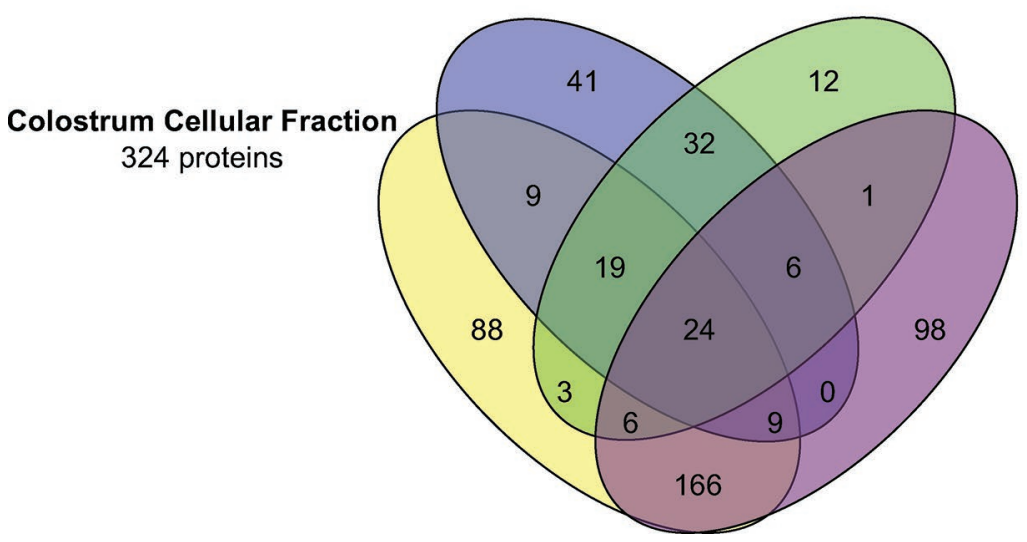

Milk Cellular Fraction 310 proteins

Figure 2. The Venn diagram presents the entire set of number of proteins found in colostrum and milk $(\mathrm{n}=514)$ in the fluid phase and cell pellet. Colostrum consisted of 324 cellular proteins and 140 fluid phase proteins. Milk consisted of 310 cellular proteins and 103 fluid phase proteins. The proteins in the top left groups, the colostrum proteins only ( 9 and 41$)$, are presented in Table 1 . The proteins in the top right groups, the milk fluid phase proteins only (12 and 1), are presented in Table 2 . The common fluid phase proteins $(19,32,24$, and 6$)$ are presented in Table 3. The remaining fluid phase proteins $(3,6$, and 9) are presented in Table 4 . Color version available online.

reproductive process, and rhythmic process. The largest difference in the number of annotations for colostrum and milk were observed for metabolic process. The GO ontology results illustrated the shift in functional potential in samples from colostrum to milk.

\section{DISCUSSION}

\section{Total Detection of Proteins by 2D-LC-MS/MS}

In total, 514 proteins were detected in the cellular and fluid phase fractions in the colostrum and milk of healthy cows, of which 162 were detected in the fluid phase (Nissen et al., 2012, 2013). The number of detected fluid-phase proteins $(\mathrm{n}=162)$ was lower than has been published in other proteome studies (Hettinga et al., 2011; Zhang et al., 2015). At calving, the likelihood of being infected by subclinical or clinical mastitis may range from 5 to almost 40\% (Bradley et al., 2015). Hence, it is crucial to test both the SCC and bacteria in colostrum and milk before sampling to rule out the presence of mastitis. Leaving out such procedures and sampling infected cows could heavily influence the milk composition and the proteome detected, because mastitis (Thomas et al., 2015) results in an increase of inflammatory proteins in the colostrum and milk samples (Boehmer et al., 2010; Danielsen et al., 2010; Smolenski et al., 2014). Hence, udder health and milk quality could explain differences in the number of proteins in colostrum and milk samples collected in different studies. Other factors that affect the sample quality are the handling, storage, and fractionation method of the samples before the 2D-LC-MS/MS analysis (Nissen et al., 2012). Also, a conservative search engine (ProteinPilot) was applied in our studies, which was reflected by the very low FDR reported. It is known that the choice of search engine influences the detection of proteins (Bruce et al., 2013). Applying a search engine with a low FDR obviously decreases the number of positive hits (Elias and Gygi, 2007). Moreover, only proteins detected in both replicates were reported and their SC calculated and presented. As reported in our previous publications, a larger number of proteins were detected in only one replicate (Nissen et al., 2012, 2013). Some of these proteins were detected simultaneously in more than one fraction (NF, F1 to F5), justifying the reporting of these as valid proteins. But as a conservative approach, we chose only to report the proteins present in both fractions of each fractionation technique. Moreover, all dominant (casein and immunoglobulin) and known contaminant proteins (trypsin and keratin) were removed from the final result files. These could not be completely eliminated by any of the fractionation techniques applied and are known to be present in colostrum and milk samples, either by their natural presence (casein and immunoglobulin; Farrell et al., 2004) or by contamination with, for instance, keratin and trypsin (Hodge et al., 2013). For this reason, we did not find these relevant to report. The above factors reduced the number of proteins but resulted in a protein detection level comparable to that of previous studies (Zhang et al., 2015). Some exceptions to this postulate are the finding of 342 proteins found in the fluid phase of ovine colostrum (Scumaci et al., 2015) and of 1,606 proteins 
in human milk and 518 in macaque milk (Beck et al., 2015). These findings reveal that much remains to be discovered about the biological role of the components in bovine colostrum and milk.

In this study, some proteins were exclusively detected in colostrum fluid phase $(\mathrm{n}=50)$, some proteins were exclusively detected in milk fluid phase $(\mathrm{n}=13)$, some proteins were common to both colostrum and the milk fluid phase $(\mathrm{n}=81)$, and some were common when considering colostrum cellular fraction and milk fluid phase fraction and vice versa $(\mathrm{n}=18)$. Relative concentration was estimated by performing spectral counting. Relative concentrations of exclusively detected proteins

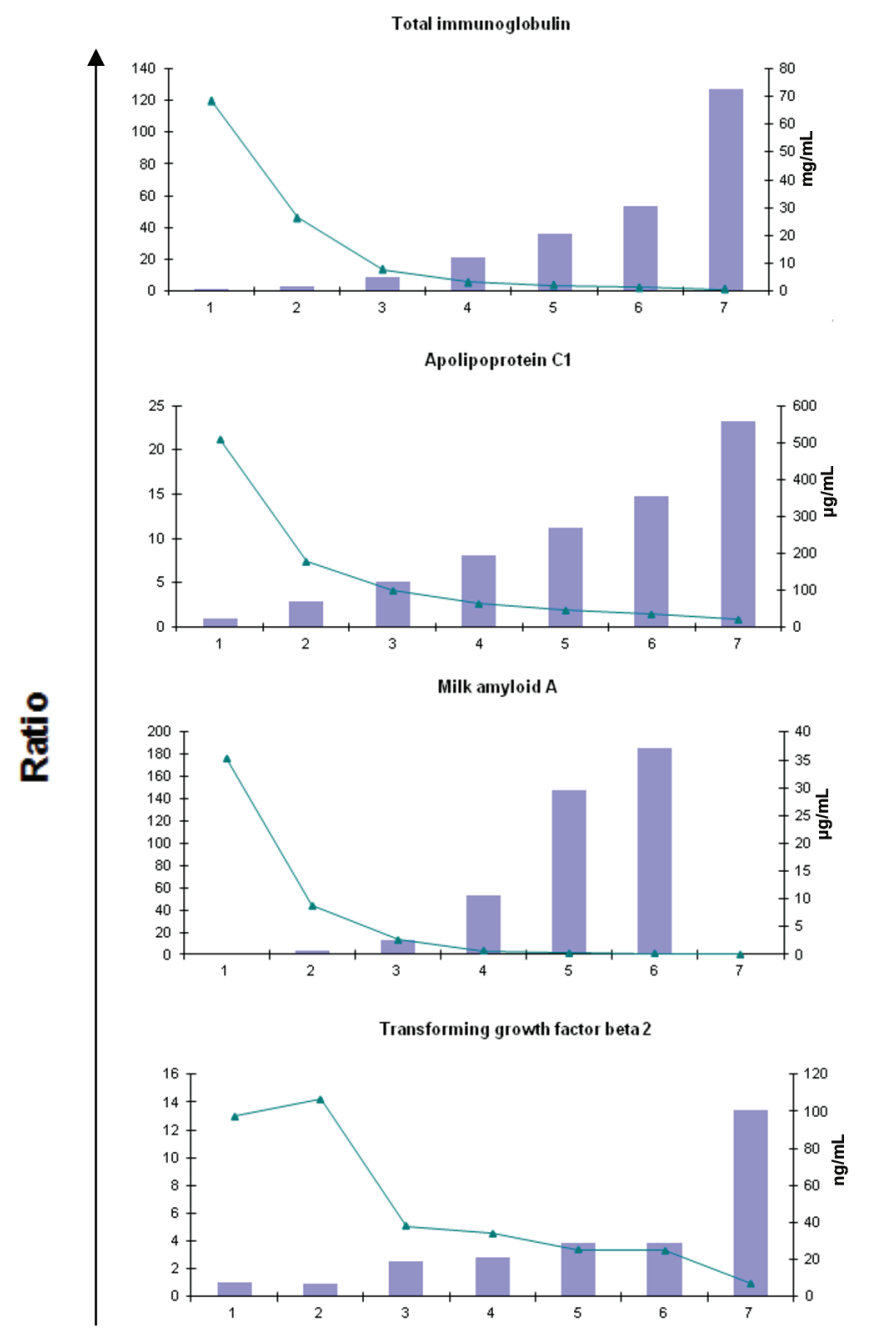

can be compared with each other, but only tentative conclusions be drawn because the tryptic peptides generated from complex protein samples like milk have very different chemical properties, which bias their detectability by mass spectrometry. For the common proteins, the SC indicates the relative change in concentration from colostrum to milk. However, it is important to remember that the analysis was performed on $50 \mu \mathrm{g}$ of precipitated proteins for both colostrum and milk, even though the protein concentration is typically 4 -fold higher in colostrum than in milk. This difference in protein content is due to some proteins being more abundant in colostrum but also to the pres-
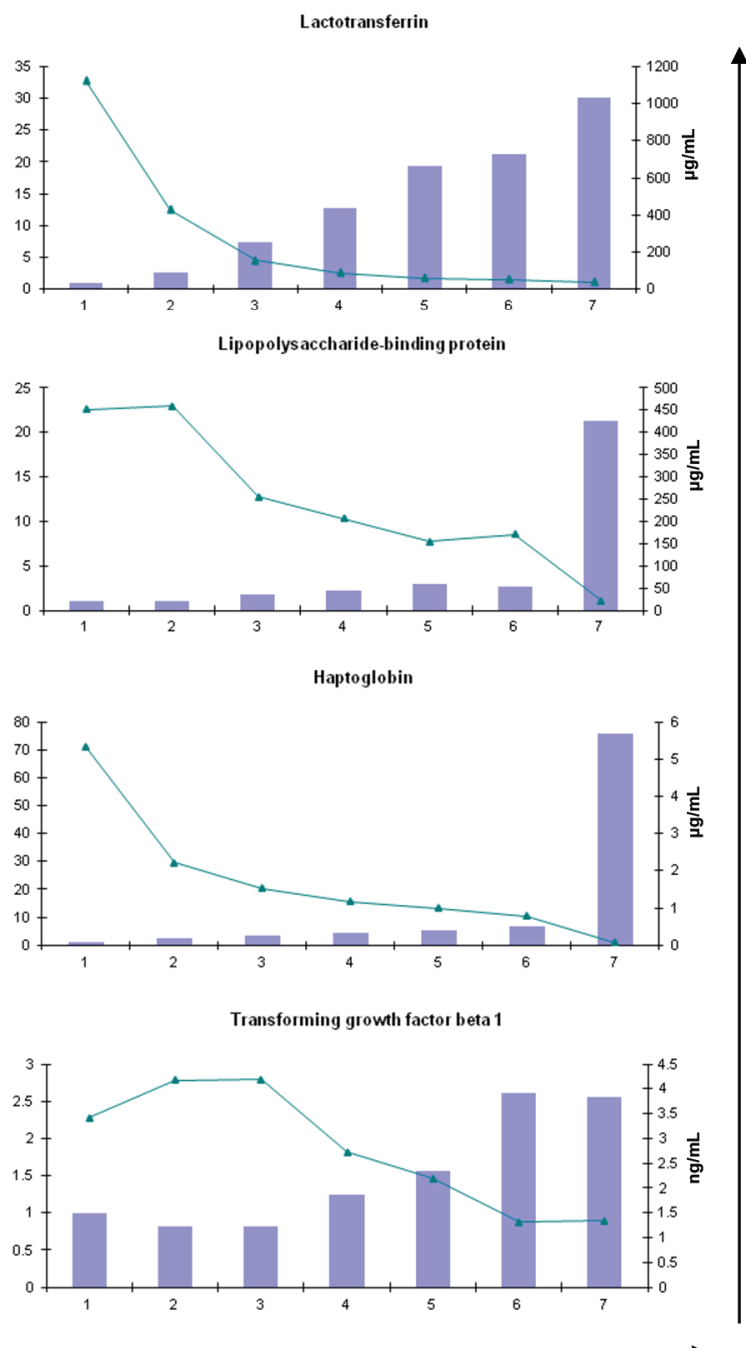

Sampling point

Figure 3. Results of ELISA on 8 selected proteins from milking number 1 (first colostrum milking; sampling point 1) through milking 6 (d 1-3; sampling point 6) to milking number 20 (milk, d 10; sampling point 7). The ratio of colostrum to the other sampling points (2-7) is shown on the left y-axis (solid bars). The concentration of each protein is shown on the right y-axis (- - ). All analyses were performed on unfractionated samples. Numeric values are presented in the Supplementary Materials (File D, https://doi.org/10.3168/jds.2016-11722). Color version available online. 


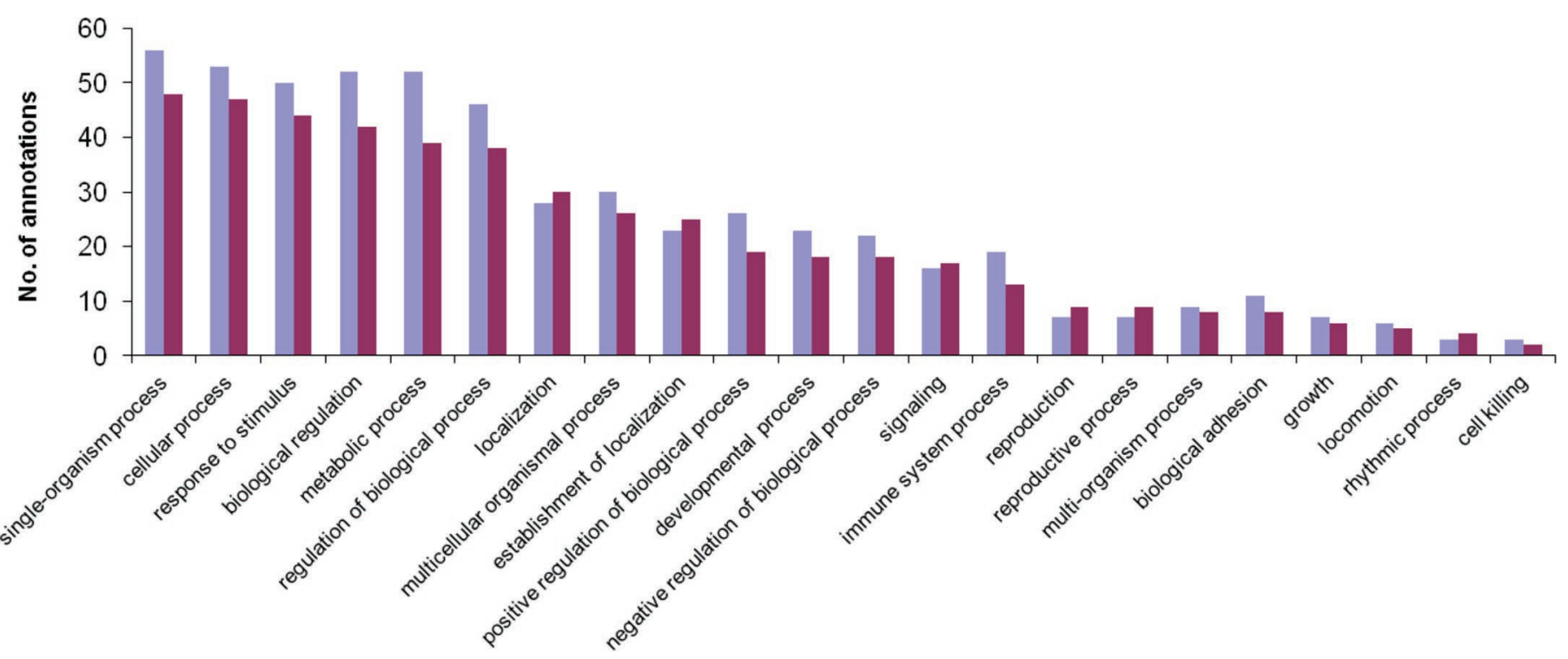

Figure 4. Gene ontology (GO) annotation showing the difference in GO annotation of colostrum (light gray/blue) and milk (dark gray/ purple). For clarity, only a subset of GO terms was used, consisting of the first leaf in the annotation tree in the biologic process category. The total number of colostrum annotations was 549 and the total number of milk annotations was 475 . Color version available online.

ence of unique proteins with other biological functions, as confirmed by our GO analysis study. The majority of the excess proteins present in colostrum were immunoglobulins, the concentration of which was determined by ELISA to be $68.0 \mathrm{mg} / \mathrm{mL}$, which is similar to what has previously been reported for Holstein cows (Lorenz et al., 2011). Therefore, the ratio presented in Table 3 only serves as a qualitative measure of what changed the most from colostrum to milk; the values themselves are not representative of the actual change. One simple example is vitamin D-binding protein. When equal amounts of protein were precipitated, as in this study, the SC ratio was 2.3 (Table 3 ). In reality, the difference is far greater, as vitamin D-binding protein is present at $250 \mu \mathrm{g} / \mathrm{mL}$ in bovine colostrum compared with $6 \mu \mathrm{g} / \mathrm{mL}$ in bovine milk - a ratio of 41.7 (Ena et al., 1992). However, from the values shown, it was not possible to obtain a factor that could be multiplied by the SC results to give an accurate measure of the real ratio, thus these result are the best possible estimates of relative protein abundances. Also, the uncertainty of estimated protein concentrations in our study was influenced by the fractionation pipelines applied (NF, F1 to F5), but we attempted to reduce this bias by treating all samples (colostrum and milk) in exactly the same way. It is important to stress that lack of detection by mass spectrometry does not necessarily mean that the protein was not present in the sample (Table 1 and Table 2) but rather that the protein was undetectable by the method and criteria applied in this study.

\section{Fluid Phase Proteins of Importance to the Calf}

As presented in the tables and Supplemental Materials (https://doi.org/10.3168/jds.2016-11722), a large number of proteins important to the calf's innate immune system, growth, and development (as well as enzyme inhibitors) were detected in the fluid phase of colostrum and milk. The biological function of some of these is summarized in Table 5, with brief descriptions and references. It is beyond the scope of this article to describe them all but we selected some proteins that we believe are important to neonatal calf health based on the biological functions described in vitro, in Bos taurus or in other species.

\section{Proteins in the Cellular Fraction of Colostrum and Milk}

Together, the cellular fractions from colostrum and milk contributed to 352 proteins (in replicate), more than twice as many proteins as in the fluid phase. To our knowledge, this is the first major proteomics study on the somatic cell pellet in colostrum and milk and therefore comprises the largest number of reported proteins for this fraction. The SCC of colostrum was more than 30-fold higher than the SCC of milk, which is in accordance with Madsen et al. (2004). Differential counts of the SCC were not conducted in this study. However, it is known that the proportion of macrophages and $\mathrm{T}$ lymphocytes is significantly higher in colostrum than in 
milk (Concha, 1986; Le Jan, 1996; Yang et al., 1997). Hence, the different proportions of cell types present in colostrum and milk make it hard to interpret the results. The finding of similar SC of the cytoskeleton protein actin suggested that equal volumes of cell material were compared. Further, the low fluid SC counts for actin suggested that only a small portion $(5-7 \%)$ of the cell-associated proteins leaked to the fluid fraction by lysis. Examples of such proteins included cathelicidin-1 and cathelicidin-2, haptoglobin, peptidoglycan recognition protein, protein S100-A9, creatine kinase B-type, and serine protease.

The cellular fraction also contained a large number of proteins not detected in the fluid phase fraction. More than 352 proteins were detected only in the cellular fraction, including antibacterial peptides and proteases. Several cathelicidins were found; namely, cathelicidins $4,5,6$, and 7 , and their function is briefly described below. Cathepsins B, D, H, S, and Z; ELA2 protein (neutrophil elastase); and $\beta$-defensin 11, 12, 13 were detected. These antimicrobial proteins and proteases are potentially present for secretion by cells upon infection (Rainard and Riollet, 2006).

Other colostrum and milk proteins were detected in both the fluid and cellular fractions. Fluid phase proteins may bind to cells in the cellular fraction either specifically via receptors or nonspecifically to viable or dead cells. Another possibility that could explain cellular protein also detected in the fluid phase is the leaking of intracellular and transmembrane proteins by lysis of the cells. It has been shown that milk from a healthy udder contains a larger number of apoptotic neutrophils in early lactation (Van Oostveldt et al., 2001). The finding of higher SC for annexin A5 in the milk cellular fraction compared with the colostrum cellular fraction supported this observation on apoptotic cells in milk.

Finally, to gain a more comprehensive picture of the somatic cell proteome, we suggest that different cell populations in the fraction are sorted either by using antibody-coated magnetic beads (Prgomet et al., 2005) or flow cytometric cell sorting (Assenmacher et al., 1995). This approach will contribute to a higher number of proteins per cell type that can be used to establish intracellular or transmembrane pathways for the investigated cell population in colostrum and milk (Cerami et al., 2011).

In contrast, some proteins are synthesized by cells in the cellular fraction and secreted to colostrum and milk; for example, MAA is synthesized in the liver and in the mammary gland. In colostrum, MAA scored 6 in the SC analysis of the fluid phase and 14 in the cell pellet. In milk, it scored 2 in the fluid phase and 2 in the cell pellet, which shows that this protein was present in higher ratio between the fluid phase and cellular fraction in colostrum and milk compared with actin, perhaps implying that MAA is synthesized and secreted by cells in colostrum. Extra-hepatic MAA expression has previously been shown in monocyte/macrophages and endothelial cells (Meek et al., 1992, 1994; Urieli-Shoval et al., 1994). The proteins in colostrum and milk can also be detected in both the fluid and cellular fraction because of binding of fluid phase proteins to the cells in the cellular fraction.

\section{ELISA Results}

Previously, 2-dimensional electrophoresis was used to demonstrate a clear difference in the content of low abundant proteins between colostrum and milk (Yamada et al., 2002; Senda et al., 2011). However, because the gel-based approach lacked sensitivity, we chose to investigate the proteome of colostrum and milk by gelfree 2D-LC-MS/MS analysis combined with ELISA of 8 preselected proteins. The ELISA measurements covered the entire dynamic range of colostrum and were conducted at 7 sample points covering the transition period from colostrum to milk. As expected, the 8 proteins, including immunoglobulins, followed the overall kinetics reported for $\operatorname{IgG}_{1}$ (Madsen et al., 2004), with concentrations peaking in colostrum and being lowest in milk collected on d 10. Nevertheless, the kinetic curves of the 8 proteins varied and could be grouped into 3 patterns. The reasons underlying these patterns and whether they can be linked to a biological purpose and functions of the protein in the newborn calf need to be further explored. Moreover, the linear detection range, the lower detection limit, and the sensitivity of the individual ELISA to the milk matrix may also have affected the pattern of these curves.

By using ELISA, we were able to demonstrate the lack of sensitivity of the proteome analysis. The 2DLC-MS/MS approach detected 5 of the 8 proteins quantified by ELISA and was unable to detect TGF-b 1 and TGF-b 2 molecules, which were quantified to nanogram per milliliter levels by their respective ELISA. One protein-APO-C-I-behaved very differently in the 2 methods. It was easily quantified by the ELISA to the microgram per milliliter level. However, it was not detected by 2D-LC-MS/MS, even though the latter method detected 5 different apolipoproteins (A-I, A-IV, $\mathrm{D}$, and E), including APO-C-III. This demonstrates that even though our study was thorough, it was far from exhaustive. An alternative explanation could be that the ELISA detected APO-C-III, and not APO-C-I.

Comparing the ranking of proteins based on ELISAdetermined protein concentrations with the proteome SC ranking of proteins illustrated that substantial 


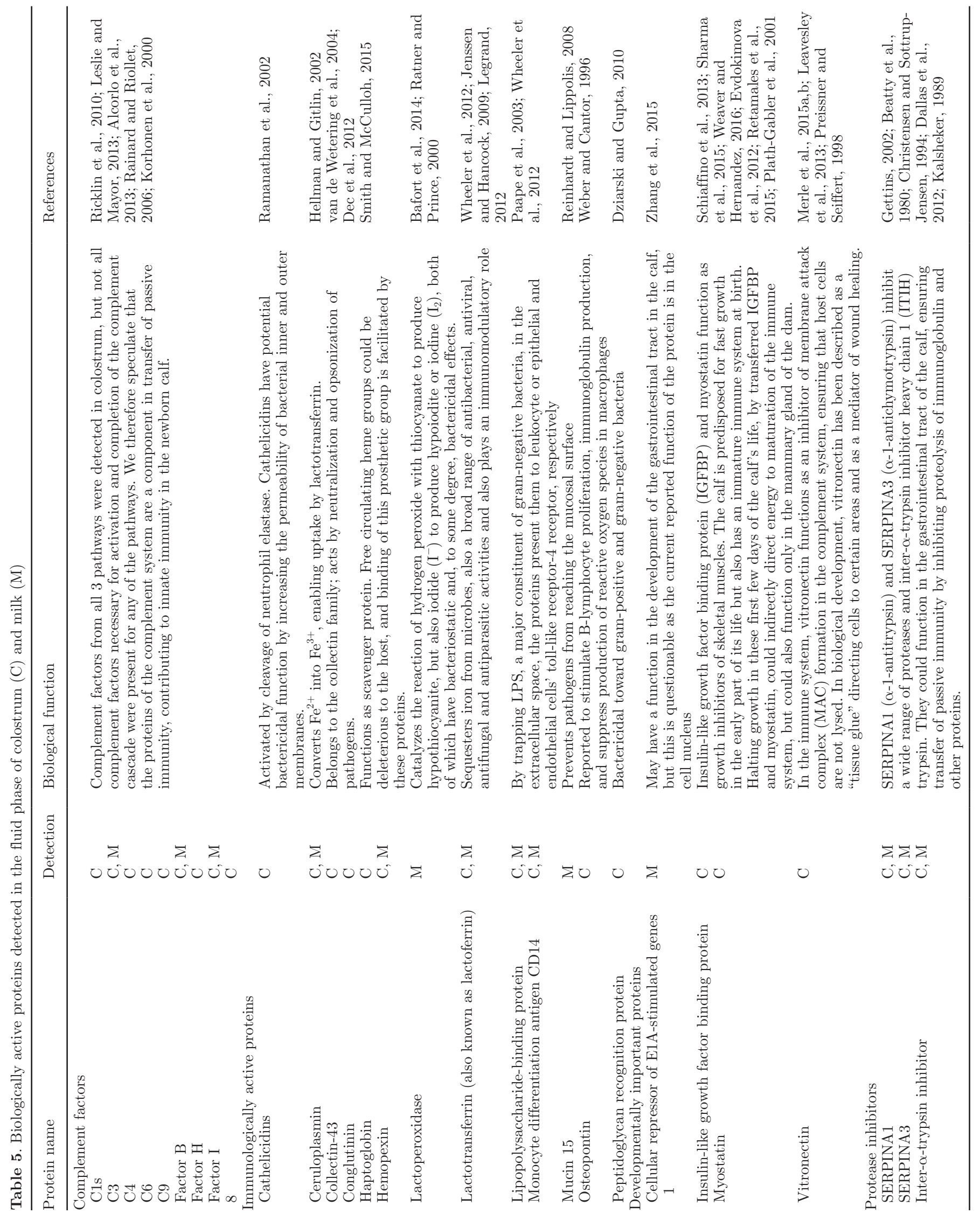


differences exist between these rankings and between the ratios. The reason for this could be masking of minor proteins by highly abundant proteins and a lower representation of the protein and its fragment in the database. Still, large-scale 2D-LC-MS/MS studies are justified because they may help to identify proteins eligible for more thorough investigation.

In our study, MAA resulted in the earliest and greatest differences in protein ratios based on protein concentration. Future studies on MAA in transition milk could help determine whether MAA is a potential indicator of the shift from colostrogenesis to normal milk production in nonmastitic cows.

Finally, further studies are needed to investigate the biological functions of the multiple proteins detected in this study, and how these are related to TPI (innate), development, and protection of the GI tract in the neonatal calf and preservation of colostrum and milk molecules within the udder and GI tract.

\section{CONCLUSIONS}

We presented a proteomic map of the total, unique, and common proteins in bovine colostrum and milk from healthy Danish Holstein-Friesian cows. A total of 514 proteins were detected, 162 of which were in the fluid phase and 352 in the cell pellet. Ranking of proteins and calculating protein ratios based on $\mathrm{SC}$ and ELISA concentrations resulted in new information on how these proteins were associated with the fluid or cellular fraction of colostrum and milk, but also revealed major differences in the ELISA and 2D-LC-MS/MS analyses in terms of method sensitivity and ranking of proteins. Although the proteome analysis suffered from lower sensitivity than the ELISA, we believe that a proteomics approach in large-scale protein studies will contribute new information and perspectives on how to prioritize the importance of multiple proteins in relation to neonatal calf health beyond just immunoglobulins.

\section{ACKNOWLEDGMENTS}

The study is part of a $\mathrm{PhD}$ project under the Research School for Animal Production and Health (RAPH) funded by the Department of Animal Science at Aarhus University (AU, Aarhus, Denmark), via funding from the Danish Ministry of Food, Agriculture and Fisheries and Copenhagen University, Faculty of Life Sciences (LIFE, Copenhagen, Denmark). Further, Calvex A/S (Skive, Denmark) is acknowledged for funding of the ELISA analysis. The technical staff at the proteome, ELISA, and microbiology laboratories at AU and the Danish Cattle Research Centre (Foulum, Denmark) is acknowledged for their contributions to the study. The authors have declared no conflict of interest.

\section{REFERENCES}

Alcorlo, M., A. Tortajada, C. S. Rodriguez, and O. Llorca. 2013. Structural basis for the stabilization of the complement alternative pathway C3 convertase by properdin. Proc. Natl. Acad. Sci. USA 110:13504-13509.

Altomare, A., E. Fasoli, M. Colzani, X. M. Parra, M. Ferrari, F. Cilurzo, C. Rumio, L. Cannizzaro, M. Carini, P. G. Righetti, and G. Aldini. 2016. An in depth proteomic analysis based on ProteoMiner, affinity chromatography and nano-HPLC-MS/MS to explain the potential health benefits of bovine colostrum. J. Pharm. Biomed. Anal. 121:297-306.

Ashburner, M., C. A. Ball, J. A. Blake, D. Botstein, H. Butler, J. M. Cherry, A. P. Davis, K. Dolinski, S. S. Dwight, J. T. Eppig, M. A. Harris, D. P. Hill, L. Issel-Tarver, A. Kasarskis, S. Lewis, J. C. Matese, J. E. Richardson, M. Ringwald, G. M. Rubin, and G. Sherlock. 2000. Gene ontology: Tool for the unification of biology. The Gene Ontology Consortium. Nat. Genet. 25:25-29.

Assenmacher, M., R. Manz, S. Miltenyi, A. Scheffold, and A. Radbruch. 1995. Fluorescence-activated cytometry cell sorting based on immunological recognition. Clin. Biochem. 28:39-40.

Bafort, F., O. Parisi, J. P. Perraudin, and M. H. Jijakli. 2014. Mode of action of lactoperoxidase as related to its antimicrobial activity: A review. Enzyme Res. 2014:517164.

Beatty, K., J. Bieth, and J. Travis. 1980. Kinetics of association of serine proteinases with native and oxidized a-1-proteinase inhibitor and a-1-antichymotrypsin. J. Biol. Chem. 255:3931-3934.

Beck, K. L., D. Weber, B. S. Phinney, J. T. Smilowitz, K. Hinde, B. Lonnerdal, I. Korf, and D. G. Lemay. 2015. Comparative proteomics of human and macaque milk reveals species-specific nutrition during postnatal development. J. Proteome Res. 14:21432157.

Boehmer, J. L., J. A. DeGrasse, M. A. McFarland, E. A. Tall, K. J. Shefcheck, J. L. Ward, and D. D. Bannerman. 2010. The proteomic advantage: label-free quantification of proteins expressed in bovine milk during experimentally induced coliform mastitis. Vet. Immunol. Immunopathol. 138:252-266.

Bradley, A. J., S. De Vliegher, M. J. Green, P. Larrosa, B. Payne, E. S. van de Leemput, O. Samson, D. Valckenier, T. Van Werven, H. W. Waldeck, V. White, and L. Goby. 2015. An investigation of the dynamics of intramammary infections acquired during the dry period on European dairy farms. J. Dairy Sci. 98:6029-6047.

Bruce, C., K. Stone, E. Gulcicek, and K. Williams. 2013. Proteomics and the analysis of proteomic data: 2013 overview of current protein-profiling technologies. Chapter 13 in Current Protocols in Bioinformatics. John Wiley and Sons, West Sussex, UK.

Bush, L. J., and T. E. Staley. 1980. Absorption of colostral immunoglobulins in newborn calves. J. Dairy Sci. 63:672-680.

Cerami, E. G., B. E. Gross, E. Demir, I. Rodchenkov, O. Babur, N. Anwar, N. Schultz, G. D. Bader, and C. Sander. 2011. Pathway Commons, a web resource for biological pathway data. Nucleic Acids Res. 39(Database issue):D685-690.

Christensen, S., and L. Sottrup-Jensen. 1994. Characterization of two serpins from bovine plasma and milk. Biochem. J. 303:383-390.

Concha, C. 1986. Cell types and their immunological functions in bovine mammary tissues and secretions-a review of the literature. Nord. Vet. Med. 38:257-272.

Dallas, D. C., M. A. Underwood, A. M. Zivkovic, and J. B. German. 2012. Digestion of protein in premature and term infants. J. Nutr. Disord. Ther. 2:112.

Danielsen, M., M. C. Codrea, K. L. Ingvartsen, N. C. Friggens, E. Bendixen, and C. M. Røntved. 2010. Quantitative milk proteomicshost responses to lipopolysaccharide-mediated inflammation of bovine mammary gland. Proteomics 10:2240-2249.

Dec, M., A. Wernicki, A. Puchalski, R. Urban-Chmiel, and A. Wasko. 2012. The effect of conglutinin on production of reactive oxygen species in bovine granulocytes. J. Vet. Sci. 13:33-38. 
Dziarski, R., and D. Gupta. 2010. Review: Mammalian peptidoglycan recognition proteins (PGRPs) in innate immunity. Innate Immun. $16: 168-174$.

Elias, J. E., and S. P. Gygi. 2007. Target-decoy search strategy for increased confidence in large-scale protein identifications by mass spectrometry. Nat. Methods 4:207-214.

Elias, J. E., and S. P. Gygi. 2010. Target-decoy search strategy for mass spectrometry-based proteomics. Methods Mol. Biol. 604:5571

Ena, J. M., M. D. Pérez, P. Aranda, L. Sánchez, and M. Calvo. 1992. Presence and changes in the concentration of vitamin-Dbinding protein throughout early lactation in human and bovine colostrum and milk. J. Nutr. Biochem. 3:498-502.

Evdokimova, V., C. E. Tognon, T. Benatar, W. Yang, K. Krutikov, M. Pollak, P. H. Sorensen, and A. Seth. 2012. IGFBP7 binds to the IGF-1 receptor and blocks its activation by insulin-like growth factors. Sci. Signal. 5:ra92.

Farrell, H. M., Jr., R. Jimenez-Flores, G. T. Bleck, E. M. Brown, J. E. Butler, L. K. Creamer, C. L. Hicks, C. M. Hollar, K. F. Ng-KwaiHang, and H. E. Swaisgood. 2004. Nomenclature of the proteins of cows' milk-sixth revision. J. Dairy Sci. 87:1641-1674.

Gettins, P. G. 2002. Serpin structure, mechanism, and function. Chem. Rev. 102:4751-4804.

Hellman, N. E., and J. D. Gitlin. 2002. Ceruloplasmin metabolism and function. Annu. Rev. Nutr. 22:439-458.

Hettinga, K., H. van Valenberg, S. de Vries, S. Boeren, T. van Hoojdonk, J. van Arendonk, and J. Vervoort. 2011. The host defense proteome of human and bovine milk. PLoS One 6:e19433.

Hodge, K., S. T. Have, L. Hutton, and A. I. Lamond. 2013. Cleaning up the masses: Exclusion lists to reduce contamination with HPLC-MS/MS. J. Proteomics 88:92-103.

Jenssen, H., and R. E. Hancock. 2009. Antimicrobial properties of lactoferrin. Biochimie 91:19-29.

Kalsheker, N. 1989. Alpha-1-antitrypsin: Structure, function and molecular biology of the gene. Biosci. Rep. 9:129-138.

Korhonen, H., P. Marnila, and H. S. Gill. 2000. Milk immunoglobulins and complement factors. Br. J. Nutr. 84(Suppl. 1):S75-S80.

Le, A., L. D. Barton, J. T. Sanders, and Q. Zhang. 2011. Exploration of bovine milk proteome in colostral and mature whey using an ion-exchange approach. J. Proteome Res. 10:692-704.

Le Jan, C. 1996. Cellular components of mammary secretions and neonatal immunity: A review. Vet. Res. 27:403-417.

Leavesley, D. I., A. S. Kashyap, T. Croll, M. Sivaramakrishnan, A. Shokoohmand, B. G. Hollier, and Z. Upton. 2013. VitronectinMaster controller or micromanager? IUBMB Life 65:807-818.

Legrand, D. 2012. Lactoferrin, a key molecule in immune and inflammatory processes. Biochem. Cell Biol. 90:252-268.

Leslie, J. D., and R. Mayor. 2013. Complement in animal development: Unexpected roles of a highly conserved pathway. Semin. Immunol. $25: 39-46$.

Lorenz, I., J. F. Mee, B. Earley, and S. J. More. 2011. Calf health from birth to weaning. I. General aspects of disease prevention. Ir. Vet. J. 64:10.

Madsen, B. D., M. D. Rasmussen, M. O. Nielsen, L. Wiking, and L. B. Larsen. 2004. Physical properties of mammary secretions in relation to chemical changes during transition from colostrum to milk. J. Dairy Res. 71:263-272.

Meek, R. L., N. Eriksen, and E. P. Benditt. 1992. Murine serum amyloid A3 is a high density apolipoprotein and is secreted by macrophages. Proc. Natl. Acad. Sci. USA 89:7949-7952.

Meek, R. L., S. Urieli-Shoval, and E. P. Benditt. 1994. Expression of apolipoprotein serum amyloid A mRNA in human atherosclerotic lesions and cultured vascular cells: Implications for serum amyloid A function. Proc. Natl. Acad. Sci. USA 91:3186-3190.

Merle, N. S., S. E. Church, V. Fremeaux-Bacchi, and L. T. Roumenina. 2015a. Complement system part I- Molecular mechanisms of activation and regulation. Front. Immunol. 6:262.

Merle, N. S., R. Noe, L. Halbwachs-Mecarelli, V. Fremeaux-Bacchi, and L. T. Roumenina. 2015b. Complement system part II: Role in immunity. Front. Immunol. 6:257.
National Mastitis Council. 1999. Laboratory Handbook on Mastitis. National Mastitis Council Inc., Madison, WI.

Nissen, A., E. Bendixen, K. L. Ingvartsen, and C. M. Rontved. 2012. In-depth analysis of low abundant proteins in bovine colostrum using different fractionation techniques. Proteomics 12:2866-2878.

Nissen, A., E. Bendixen, K. L. Ingvartsen, and C. M. Rontved. 2013. Expanding the bovine milk proteome through extensive fractionation. J. Dairy Sci. 96:7854-7866.

Paape, M. J., D. D. Bannerman, X. Zhao, and J. W. Lee. 2003. The bovine neutrophil: Structure and function in blood and milk. Vet. Res. 34:597-627.

Plath-Gabler, A., C. Gabler, F. Sinowatz, B. Berisha, and D. Schams. 2001. The expression of the IGF family and GH receptor in the bovine mammary gland. J. Endocrinol. 168:39-48.

Preissner, K. T., and D. Seiffert. 1998. Role of vitronectin and its receptors in haemostasis and vascular remodeling. Thromb. Res. 89:1-21.

Prgomet, C., H. Sarikaya, R. M. Bruckmaier, and M. W. Pfaffl. 2005 Short-term effects on pro-inflammatory cytokine, lactoferrin and CD14 mRNA expression levels in bovine immunoseparated milk and blood cells treated by LPS. J. Vet. Med. A Physiol. Pathol. Clin. Med. 52:317-324.

Pyörälä, S. 2003. Indicators of inflammation in the diagnosis of mastitis. Vet. Res. 34:565-578.

Rainard, P., and C. Riollet. 2006. Innate immunity of the bovine mammary gland. Vet. Res. 37:369-400.

Ramanathan, B.. E. G. Davis, C. R. Ross, and F. Blecha. 2002. Cathelicidins: Microbicidal activity, mechanisms of action, and roles in innate immunity. Microbes Infect. 4:361-372.

Ratner, A. J., and A. Prince. 2000. Lactoperoxidase. New recognition of an "old" enzyme in airway defenses. Am. J. Respir. Cell Mol. Biol. 22:642-644.

Reinhardt, T. A., and J. D. Lippolis. 2008. Developmental changes in the milk fat globule membrane proteome during the transition from colostrum to milk. J. Dairy Sci. 91:2307-2318.

Retamales, A., R. Zuloaga, C. A. Valenzuela, C. Gallardo-Escarate, A. Molina, and J. A. Valdes. 2015. Insulin-like growth factor-1 suppresses the Myostatin signaling pathway during myogenic differentiation. Biochem. Biophys. Res. Commun. 464:596-602.

Ricklin, D., G. Hajishengallis, K. Yang, and J. D. Lambris. 2010. Complement: A key system for immune surveillance and homeostasis. Nat. Immunol. 11:785-797.

Schiaffino, S., K. A. Dyar, S. Ciciliot, B. Blaauw, and M. Sandri. 2013. Mechanisms regulating skeletal muscle growth and atrophy. FEBS J. 280:4294-4314.

Scumaci, D., F. Trimboli, L. Dell'Aquila, A. Concolino, G. Pappaianni, L. Tamme, G. Vignola, A. Luciani, D. Morelli, G. Cuda, A. Boari, and D. Britti. 2015. Proteomics-driven analysis of ovine whey colostrum. PLoS One 10:e0117433.

Senda, A., K. Fukuda, T. Ishii, and T. Urashima. 2011. Changes in the bovine whey proteome during the early lactation period. Anim. Sci. J. 82:698-706.

Sharma, M., C. McFarlane, R. Kambadur, H. Kukreti, S. Bonala, and S. Srinivasan. 2015. Myostatin: Expanding horizons. IUBMB Life 67:589-600.

Smith, A., and R. J. McCulloh. 2015. Hemopexin and haptoglobin: Allies against heme toxicity from hemoglobin not contenders. Front. Physiol. 6:187.

Smolenski, G. A., M. K. Broadhurst, K. Stelwagen, B. J. Haigh, and T. T. Wheeler. 2014. Host defence related responses in bovine milk during an experimentally induced Streptococcus uberis infection. Proteome Sci. 12:19.

Stelwagen, K., E. Carpenter, B. Haigh, A. Hodgkinson, and T. T. Wheeler. 2009. Immune components of bovine colostrum and milk. J. Anim. Sci. 87(Suppl.):3-9.

Stott, G. H., D. B. Marx, B. E. Menefee, and G. T. Nightengale. 1979. Colostral immunoglobulin transfer in calves I. Period of absorption. J. Dairy Sci. 62:1632-1638.

Thomas, F. C., M. Waterston, P. Hastie, T. Parkin, H. Haining, and P. D. Eckersall. 2015. The major acute phase proteins of bovine milk in a commercial dairy herd. BMC Vet. Res. 11:207. 
Urieli-Shoval, S., R. L. Meek, R. H. Hanson, N. Eriksen, and E. P. Benditt. 1994. Human serum amyloid A genes are expressed in monocyte/macrophage cell lines. Am. J. Pathol. 145:650-660.

van de Wetering, J. K., L. M. van Golde, and J. J. Batenburg. 2004 Collectins: Players of the innate immune system. Eur. J. Biochem. 271:1229-1249.

Van Oostveldt, K., F. Vangroenweghe, H. Dosogne, and C. Burvenich. 2001. Apoptosis and necrosis of blood and milk polymorphonuclear leukocytes in early and midlactating healthy cows. Vet. Res. 32:617622. http://dx.doi.org/https://doi.org/10.1051/vetres:2001143.

Weaver, D. M., J. W. Tyler, D. C. VanMetre, D. E. Hostetler, and G. M. Barrington. 2000. Passive transfer of colostral immunoglobulins in calves. J. Vet. Intern. Med. 14:569-577.

Weaver, S. R., and L. L. Hernandez. 2016. Autocrine-paracrine regulation of the mammary gland. J. Dairy Sci. 99:842-853.

Weber, G. F., and H. Cantor. 1996. The immunology of Eta-1/osteopontin. Cytokine Growth Factor Rev. 7:241-248.

Wheeler, T. T., G. A. Smolenski, D. P. Harris, S. K. Gupta, B. J. Haigh, M. K. Broadhurst, A. J. Molenaar, and K. Stelwagen. 2012. Host-defence-related proteins in cows' milk. Animal 6:415-422.
Wu, C. H., R. Apweiler, A. Bairoch, D. A. Natale, W. C. Barker, B Boeckmann, S. Ferro, E. Gasteiger, H. Huang, R. Lopez, M. Magrane, M. J. Martin, R. Mazumder, C. O'Donovan, N. Redaschi, and B. E. Suzek. 2006. The Universal Protein Resource (UniProt): An expanding universe of protein information. Nucleic Acids Res. 34:D187-D191.

Yamada, M., K. Murakami, J. C. Wallingford, and Y. Yuki. 2002. Identification of low-abundance proteins of bovine colostral and mature milk using two-dimensional electrophoresis followed by microsequencing and mass spectrometry. Electrophoresis 23:1153-1160.

Yang, T. J., I. A. Ayoub, and M. J. Rewinski. 1997. Lactation stagedependent changes of lymphocyte subpopulations in mammary secretions: Inversion of $\mathrm{CD} 4+/ \mathrm{CD} 8+\mathrm{T}$ cell ratios at parturition. Am. J. Reprod. Immunol. 37:378-383.

Zhang, L., S. Boeren, J. A. Hageman, T. van Hooijdonk, J. Vervoort, and K. Hettinga. 2015. Bovine milk proteome in the first 9 days: Protein interactions in maturation of the immune and digestive system of the newborn. PLoS One 10:e116710. 